\title{
Fiscal reform and the tax burden of state-owned enterprise in China
}

\author{
Yong-Ching Chiou a*, Yao-Chih Hsieh b, Wenyi Lin c \\ a Department of Insurance and Finance, National Taichung University of Science and Technology, Taiwan, R.O.C \\ b Department of Public Finance, Feng Chia University, Taiwan, R.O.C \\ c Graduate Institute of Financial and Economic Law, Feng Chia University, Taiwan, R.O.C \\ ${ }^{*}$ Corresponding author's e-mail: yvonne@nutc.edu.tw
}

\section{H I G H L I G H T S:}

1. This study examines the link between state-owned enterprises (SOEs) and effective tax rates (ETRs) in China.

2. This study attempts to adopt institutional environments, the state-owned enterprises taxation reform and China's Communist Party on the regulations of state-owned enterprises, and proposes the state-owned enterprise hypothesis.

3. The use of quantile regression model not only explains different levels of ETR across firms when tax policies offer a variety of tax preferences but also considers the extreme low or high ETRs.

4. Results suggest that SOEs are an important determinant of ETR in China. China's SOEs pay higher effective tax rates and the results are consistent with the SOE hypothesis.

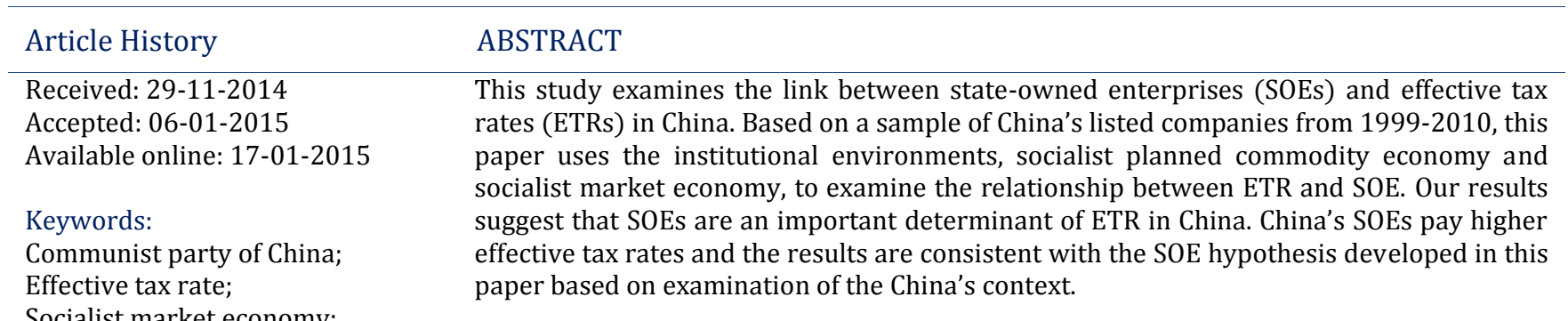

Socialist market economy;

State-Owned Enterprise.

JEL Classification:

H11; H21; H25; H32.

DOI: http://dx.doi.org/10.18533/jefs.v3i01.102

(C) 2015 The Authors. This is an open access article under the terms of the Creative Commons Attribution License 4.0, which allows use, distribution and reproduction in any medium, provided the original work is properly cited.

\subsection{Introduction}

Tax policy has been a major issue since researchers assessed the company's effective tax rate (ETRs) determinants. Several studies have concentrated on company size and ETR relationship, that is to say, political power or political cost hypothesis (e.g. Kern and Morris, 1992; Kim and Limpaphayom, 1998; Porcano, 1986; Wilkie and Limberg, 1990; Zimmerman, 1983). Several studies have addressed the relationship between the impact of the industrial sector and the ETR (for example, Derashid and Zhang, 2003; Gupta and Newberry, 1997; Kern and Morris, 1992; Zimmerman, 1983).

Ever since researchers, assessing the determinants of the variability in corporate effective tax rates (ETRs) have been a leading topic in the tax policy literature. Some studies focus on the relationship between firm size and ETRs, that is, political power hypothesis or political cost hypothesis (e.g., Kern and Morris, 1992; Kim and Limpaphayom, 1998; Porcano, 1986; Wilkie and Limberg, 1990; Zimmerman, 1983). Some studies concern the relationship between 
industrial sector effects and ETRs (e.g., Derashid and Zhang, 2003; Gupta and Newberry, 1997; Kern and Morris, 1992; Zimmerman, 1983).

Recently, some articles focus on the topic of state-owned enterprises (SOEs). Derashid and Zhang (2003) indicate that government ownership in a firm may reduce the ETR of the firm by lobbying government departments in Malaysia and the empirical results show that no relationship between ETRs and SOEs, whereas Adhikari et.al (2006) argue that because of relationship-based (with political connections being an important form of relationship), the Malaysian government plays the role of political patron to the selected firms. And the empirical result is firms with political connections pay tax at lower effective rates. Wu et al. (2007) argue SOEs in China pay higher ETRs because SOEs are more sensitive to politics. However, their empirical results indicate the relationship between ETRs and SOEs is insignificant. Liu and Chao (2007) use the listed companies' data in China and their empirical results show the relationship between ETRs and SOEs is significant. Later Huang et al. (2013) get the same results as Wu et al (2007).

Those previous empirical results lack consistency. Besides, given that these studies are main concern other determinants, the relevance questions for the roles of SOE are not discussed. Can those results from previous research be accepted?

To review China's experience of fiscal reform since 1978, both SOE reform and state-owned economy strategic restructuring accompanies the fiscal reform. The institutional environments are significantly important in China. An analysis of the Communist Party of China (CPC) on SOE policy management effects and the relationship between ETR and SOE are necessary to examine again. Research concerning the importance of SOE as a determinant of ETR is important for several reasons. First, China is the world's second largest economy and the SOEs play a very important role in her socialist market economy. Second, very little is currently discussed SOE is one of the ETRs' determinants. Finally, the omission of SOE from studies of ETR may create unreliable results, especially in China.

This study contributes to the ETR on China's firms by investigating the connection between SOE and ETR in China. The contribution is relevant to socialist market economy in at least three ways. First, the regulations of CPC on behaviors of SOE are important factors in the study of ETR in China. Second, China is the second largest economy in the world and SOE is an important factor for China to implement her economy activities. Finally, based on institutional assessment of China, this study examines the possible link between ETR and SOE behaviors, i.e., the state-owned enterprise hypothesis.

The rest of this article is organized as follows. An introduction of the institutional environments of fiscal reform is provided in section 2. Section 3 introduces determinants of ETR and data. Section 4 discusses the empirical results. Conclusions are in Section 5.

\subsection{State-owned enterprises in China's institutional environment}

In this section, this paper first considers the state-owned enterprises' taxation reform. Then we discuss how the CPC affects the behaviors of SOE.

\subsection{The state-owned enterprises' income taxation reform}

Fiscal reform began with the reform of the power delegation and profit-sharing of SOEs. SOE profit distribution was closely related to the fiscal system. Furthermore, both SOE reform and state-owned economy strategic restructuring accompanied the fiscal reform. Fiscal reform started with the enterprise rights expansion.

From 1978, SOEs were in a trial implementation of the enterprise fund system, meaning that from then on, all the enterprises that fulfilled the following annual targets of production quota, assortment, raw materials, fuel and power consumption, labor productivity, cost, profit and circulation fund used, and so on, could draw 5 percent of the total wages of workers throughout the year as an enterprise fund. Those that hit only four annual plan targets, namely production, assortment, quantity and profits, and supply contract could draw 3 percent of the total wages of workers throughout the whole year as an enterprise fund. For each additional target achieved, another 0.5 percent of total wages would be awarded. For those that failed to accomplish these four targets and supply contract, no fund could be drawn.

For the administrative units of enterprises, after balancing all the enterprises' profits and losses under their control, they could draw the extra profit that surpassed the state annual plan target as their enterprise fund. In October 1979, the provisions for enterprise funds were adjusted. In some industrial enterprises there were trial implementations of the profit retention system, according to which enterprises could retain 40 percent of the increased profit and turn in 60 percent of the increased profit. At first, all the profits were calculated for profit retention, of which only technology profit and increased profit were retained. 
To make the profit distribution relationship the state and SOEs normative, from 1983to 1984, China carried out two steps of reforming the substituting tax payment for profit delivery. It was not only a taxation reformation but also a reform of the profit distribution relationship between the central government and SOEs. The positive effect of substituting tax payment for profit delivery was making breakthroughs by levying a tax on SOEs, which made it possible for the central government to control the operations of enterprises. At the beginning of reforms and openingup, substituting tax payment for profit delivery was the most important taxation reform. Taxation reform began after substituting tax payment for profit delivery. Substituting tax payment for profit delivery consisted of two steps.

On January1, 1983, China began the first step of the scheme of substituting tax payment for profit delivery. This step both tax payment and profit delivery coexisted. To realize profits from large- and medium-sized enterprises, income tax would be imposed; then profits that came after the initial income tax would be distributed in some ways between the state and enterprises. On September 18, 1984, the State Council promulgated the Second Step of Substituting Tax Payment for Profit Delivery for State-Owned Enterprises (which became effective on October 1, 1984). The second step was to turn in all the enterprise profit delivery in terms of tax based on a gradual reasonable pricing system and the elevated levels of enterprise management. Small-sized SOEs completed the reform from profit delivery to tax payment in one step.

At the beginning of 1979, some industrial enterprises implemented substituting tax payment for profit delivery. There were more than 30 types of experiments. The common experiment was to treat the enterprise income tax as the main category with a tax rate of 55 percent.

On January 1, 1983, China began substituting tax payment for profit delivery. The first step of the scheme substituting tax payment for profit delivery distinguished between five types of enterprises: (1) State-owned large- and mediumsized that could earn profit (including financial and insurance institutions). (2) State-owned small-sized enterprises that are profitable. (3) Hotels, restaurants, rest houses, and catering service enterprises in operations. (4) Supply marketing cooperatives above country level. (5) Military-related enterprises, postal and telecommunications enterprises, grain enterprises, foreign trade enterprises, agricultural and husbandry enterprises, and reformative enterprises.

Different tax-for-profit measures were applicable to the five types of enterprises; firstly, for profitable state-owned large- and medium-sized enterprises (including financial and insurance institutions), income tax is paid as per 55 percent of realized profit. A certain proportion of remaining profit was paid to state and others reserved by the enterprises as per profit reserved according to a proportion ratified by the state. The tax due to the state was paid according to the enterprises' condition, in terms of overall progressive ratios, fixed ratios, regulation tax and overall progressive quotas (only meant for mining enterprises). Secondly, for profitable small-sized state-owned enterprises, income tax was paid according to the eight-grade progressive tax rates based on its realized profit. Thirdly, for operating hotels, restaurants, rest houses, and catering service enterprises, 15 percent of the profits were paid as income tax without any allocated funds from the state. Fourthly, for supply marketing cooperatives above county level, income tax were paid as per the eight-grade progressive tax rates with county enterprises or county supply marketing cooperatives as the legal taxed unit. Fifth, for military-related enterprises, postal and telecommunications enterprises, grain enterprises, foreign trade enterprises, agricultural and husbandry enterprises, and reformative enterprises, income was paid as per previous practice. The implementation of the substituting tax payment for profit delivery guaranteed the state interest (fiscal revenue), emphasized the responsibility of the enterprises, increased the incentives of enterprises and workers, and promoted economic activities.

On September 18, 1984, the State Council promulgated the Second Step of Substituting Tax Payment Profit Delivery for State-Owned Enterprises (which became effective on October 1,1984). In accordance with tax objects, it divided industrial and commercial tax into product tax, VAT, the salt tax, and business tax. It also improved the income tax and regulation tax established in the first step of substituting tax payment for profit delivery and introduced new tax categories, including resource tax, urban maintenance and construction tax, real estate tax, land use tax, vehicle and vessel usage tax. The second step is substituting tax payment for profit delivery substituted turn-in fiscal revenue. The co-existing status of tax payment and profit delivery that transformed into fully substituting tax payment for profit delivery was an all-around reform of China's industrial and commercial taxation. The SOE income tax was one of the main tax categories at the second step of substituting tax payment for profit delivery.

The basic framework of China's industrial and commercial taxation system formed after the second step of substituting tax payment for profit delivery. Objectives of the industrial and commercial taxation reform in 1994 can be summarized as follows. Firstly, the aim was to guarantee fiscal revenue by gradually increasing tax revenue as a percentage gross national product (GNP) through taxation reform. The second was to improve economic efficiency. By unifying domestic corporate income tax rate at 33 percent on January 1, 1994, various enterprises would be faced with fair tax burdens. 
China integrated the domestic enterprises' income taxation system with the separation of the domestic and foreign enterprise income taxation system. New corporate income tax law was passed in 2007 and came into force in 2008. Under new corporate income taxation system, either domestic or foreign enterprises were subjected the same tax rate of 25 percent. Domestic enterprises were faced with the opportunity of fair competition and co-development with foreign enterprises. It was consistent with the requirement of the market economy.

\subsection{Communist Party of China on the regulations of state-owned enterprises}

China's economic reform has always been supported by the fiscal system, and both the formation of a market-oriented economy and the deepening of the economic reform are inseparable from fiscal reform. In fact, fiscal reform created an appropriate external environment to ensure economic development and the key essence of the fiscal reform is aligning the direction of the market-oriented economy.

This section we consider three stages of China's economic reform. The early stage of China's economic reform (1978 to 1983), in 1978, the Third Plenary Session of the 11th Central Committee of the Communist Party of China (CCCPC) emphasized the economic construction and proposed expansion of policies to encourage the autonomous decisionmaking of local and agricultural enterprises under state-planned guidance so as to stimulate the initiative, proactively and creativity of the following instructions: the central government, the local governments, the enterprises, and labor. Meanwhile, agricultural was emphasized as the basis of the state economy. In April 1979, the central government introduced the policy of readjusting, restructuring, consolidating, and upgrading the state economy and this improved some of major economic indicators, such as the proportion between agriculture and industry and proportion between savings and consumption. After the economic reform, agriculture production recovered and developed, enterprises improved their performance, and the local economies were strengthened. The supply of goods and commodities improved to a great extent. In some regions, the buyers' market also grew. Reforms in this phase were guided by the principle of relying mainly on the planned economy while making market adjustments in the background. Along with the reform of the traditional planned economy, the following developed to some extent: the individual economy, the township enterprises, and foreign-invested enterprises.

The second stage economic reform is Socialist planned commodity economy (1984 to 1991). On October 20, 1984, the Third Plenary Session of the 12th CCCPC approved the CCCPC Decision on Economic Reform in which the goals of socialist planned commodity economic reform were proposed as the central government realized that the planned economy could not coexist with commodity economy. In 1987, the 13th National Congress of the CPC pointed out that China was in her socialist primary stage and the main tasks include making public ownership widespread and developing the planned commodity economy. At this stage, public ownership was a prerequisite to developing a multiple ownership economies, and distribution on the basis of labor was also a prerequisite to developing other kinds of distribution. The 13th National Congress of the CPC also pointed out that the instructional plan did not suit the development of a socialist commodity economy and the state should turn to indirect control of enterprises gradually. Both the state and the market should play complementary roles: the state should regulate the market, and the market should guide enterprises. The central task of transforming the enterprise operating system was preceded by a phased reform to build a new planned commodity economy framework. The scope of reform covered planning, investment, goods and materials, finance, banking, foreign trade, and so on. Passed in 1988, the Law of the People's Republic of China on Industrial Enterprises Owned by the People defines the rights and obligations of industrial enterprises owned by the people and clarifies that industrial enterprises owned by the people were business units engaged in socialist commodity production that legally made their own management decisions and took full responsibility for their own profits and losses with independent accounting. Besides, the law pointed out that enterprises could adopt a responsibility system in business operations such as contracting and leasing.

The third stage China's economic reform from 1992 to the present is socialist market economy. For a long time, the planned economy and the market economy symbolized socialism and capitalism, respectively. Although the planned commodity economy goal was set, the effects of the planned economy could not be eradicated immediately, and with the reform deepening, it became more and more clear that the planned economy constrained China's economic development. The market's important role in allocating resources had to be ensured. At the start of 1992, Deng Xiaoping delivered a speech during his tour to southern China and pointed out that the proportion of planning to market forces is not an essential difference between socialism and capitalism. A planned economy is not equivalent to socialism, because there is planning under capitalism too; a market economy is not capitalism, because there are planned markets, too. Planning and market forces are both means of controlling economic activity. From then on, the market economy was no longer forbidden in China.

On July 23, 1992, the Regulation on the Transformation of Operational Mechanism of Industrial Enterprises Owned by the People was promulgated. The purpose of promoting the enterprises owned by people was to access the markets, enhance the vitality of the enterprises. Objectives for the transformation of the operational mechanism of enterprises were to make them adapt to market demands, change them into commodity-producing and self-managed 
entities that conducted independent business operations, assumed sole responsibility for their own profits and losses, and were capable of self-development and self-restraint. The law also turned enterprises into legal entitles that independently enjoyed civil rights and assumed civil obligations. This regulation proposed that the contractual management responsibility system be continuously implemented and improved. The central government gradually and experimentally separated profit from tax, unified income tax rates, exempted enterprises from after-tax burden, realized the repayment of loans after the tax payment, and created conditions for the experimental implementation of the shareholding system.

In October 1992, the 14th National Congress of the CPC announced the goals of the socialist market economic reform. In November 1993, the Third Plenary Session of the 14th CCCPC approved the Decisions on Issues Regarding the Establishment of a socialist Market Economy in which the economic reform goals were summarized as follows: the market should play the primary role in resource allocation under the state's macro regulation and control; to develop the socialist economy, a modern enterprise system should be established; a national, unified and open market system should be established; the government's fiscal role should be changed; indirect macro regulation and a control system should be established; a distribution system of relying mainly on labor and efficiency while taking fairness into account should be established; and a multi-level social security system should be established.

On September 22, 1999, the Fourth Plenary Session of the 15th CCCPC approved the CCCPC Decisions on SOE Reform and Development Issues, which required the SOE system reform to speed up, and the mechanism transformation, structural adjustment, and technology improvement to rescue the SOEs, which had to complete within three years. Based on the condition then, key industries, enterprises, and old industrial bases needed much more attention in order to solve current issues and enable long-term development. Based on the industrial structure upgrade and ownership structure adjustment, and state-owned economy had to be restructured to improve the state-owned economy. On October 14, 2003, the Third Plenary Session of the 16th CCCPC released the CCCPC Decisions on Improvement of the Socialist Market Economy, which created multiple modes of public ownership to accelerate the adjustment the state-owned economic structure. The state-owned economic reform was closely connected to the building of the socialist market economy. The SOEs' major function was to provide fiscal revenue and thereby regulate and control the national economy.

Given the three stages of economic development in China, including early stage of China's economic reform, social planned commodity economy, and social market economy, may be given to SOEs in order to support government to implement the policy goals. One result of these policies is that establishment the state-owned enterprises' taxation system is closely connected to the state-owned economic reform. Such a policy provides the possible connection between ETR and SOE policy, i.e., the state-owned enterprise hypothesis.

\subsection{Data and Methodology}

The determinants of a firm's determinants of ETRs have been discussed extensively by above studies, which suggest a number of firm characteristics that may impact upon a firm's ETR. Following their analysis, we postulate that ETR is determined by the following regression:

$$
\mathrm{ETR}_{\text {it }}=\alpha_{0}+\alpha_{1}\left(\mathrm{SIZE}_{\mathrm{it}}\right)+\alpha_{2}\left(\mathrm{LV}_{\mathrm{it}}\right)+\alpha_{3}\left(\mathrm{II}_{\mathrm{it}}\right)+\alpha_{4}\left(\mathrm{CI}_{\mathrm{it}}\right)+\alpha_{5}\left(\mathrm{ROA}_{\mathrm{it}}\right)+\alpha_{6} \mathrm{~S}_{\mathrm{it}}+\alpha_{7} \mathrm{D}_{\mathrm{t}}+\mathrm{IND}_{1}+\cdots+\mathrm{IND}_{\mathrm{n}}+\mathrm{u}_{\mathrm{it}}
$$

where $\mathrm{i}, \mathrm{t}$ and $\mathrm{n}$ are indices of the firm and the year and different industries, $\alpha_{0}$ is the constant and $\mathrm{u}$ is the error term.

\begin{tabular}{|c|c|c|c|}
\hline \multicolumn{4}{|c|}{ Table 01: Variable list } \\
\hline \multicolumn{4}{|c|}{ Dependent variables } \\
\hline ETR1 & Porcano & 1986 & (Income tax expense - deferred tax expense) / income before tax net \\
\hline ETR2 & Porcano & 1986 & income tax expense / profit before tax and interest payments \\
\hline ETR3 & Stickney and McGee & 1982 & $\begin{array}{l}\text { tax expenses/ (pre-tax profit- (deferred tax expenses/statutory tax } \\
\text { rate)) }\end{array}$ \\
\hline ETR4 & Shevlin & 1987 & $\begin{array}{l}\text { (tax expenses-deferred tax expenses)/ (pre-tax profit - (changes in } \\
\text { deferred tax/statutory tax rate }\end{array}$ \\
\hline \multicolumn{4}{|c|}{ Control variables } \\
\hline LV & leverage & & total liabilities divided by total asset value \\
\hline CI & capital intensity & & total net fixed assets divided by total assets \\
\hline II & inventory intensity & & inventory divided by total as \\
\hline ROA & return on assets & & pre-tax profit divided by total assets \\
\hline SIZE & Company size & & the natural logarithm of total asset value \\
\hline
\end{tabular}

Stickney and McGee (1982) used data from 1978-1980, taking into account the company size, capital intensity, financial leverage, the use of natural resources and the location of the company (domestic or foreign) and other five 
variables to analyze the factors that affect the effective tax rate. The empirical results show that for the enterprises having higher debt financing and be more capital-intensive, its higher deductibles, can lower its effective tax rate, and therefore it is found that capital intensity, financial leverage and natural resource extraction were negatively related to the effective tax rate, while company size and location of the company had little impact on the effective tax rate.

Zimmerman (1983) in 1947-1981 and IRS SOI Compustat database-line research, studied the relationship between company size and the effective tax rate, and the effective tax rate is defined as the corporate income tax (domestic and foreign) divided by operating cash flow. The empirical results found that the larger the companies are, the more vulnerable they are to government monitoring, resulting in

higher political costs, and are positively correlated with the company size and the effective tax rate, in line with the political cost hypothesis.

Porcano (1986) used the Value Line Data Base in 1982 and 1983 as the sample database to conduct empirical research, and defined the effective tax rate as follows: 1 . (Income tax expense - deferred tax expense) / income before tax net; 2. (Income tax expense) / (net profit before interest and tax). Empirical results show that the greater the size of the company, the greater the resources they have to engage in political lobbying or participate in the development of policies to fight for more tax incentives, and therefore the tax burden on enterprises decreases as size increases, and that is to say company size and the effective tax rate are negatively related to political power in line with the hypothesis.

Wilkie-Limberg (1990) studied the differences in reasons of both Zimmerman (1983) and Porcano (1986). Empirical results show that differences in empirical research programs, such as the way to define effective tax rate (including income abroad or not), the sample selection program (database and sampling year), and data integration methods (weighted or not when calculating the effective tax rate in each group), are the main reasons why Zimmerman (1983) and Porcano (1986) obtained different study results.

Gupta and Newberry (1997) examined the relationship between company size and the effective tax rate. They found that after TRA86 Act implementation, there is no significant correlation between the long survival time with the size of the company and its effective tax rate; And when they expand this sample group by adding in relatively short survival companies, the company's size with the effective tax rate has a significant correlation, but no significant positive or negative number, which indicates that the relationship between company size and the effective tax rate will change over time. In fact, they found that among the larger companies, a higher effective tax rate can be associated before the implementation of TRA86, while a lower effective tax rate can be associated after the implementation of the TRA86. However, it does not support the Citizens for Tax Justice (1988) univariate results.

Xing Liu and Shujun Cao (2007) tested which variables will affect the company's effective tax rate, and they used data of listed companies in China from 1988-2004. They found that the size of the asset-intensive companies had no significant correlation with an effective tax rate, while financing leverage is negatively related to the effective tax rate. But there is a more specific comparison variables namely indicators of excessive hiring workers, they found that this indicator and the effective tax rate presented a significant negative correlation, and the negative impact is very great. It is estimated that because the labor hiring is compliance with the incentives provided by the government. The relationship between profitability and equity ownership and the effective tax rate differs as external conditions differ.

We follow the approach used by Porcano (1986) and ETR1 is defined as tax expenses minus deferred tax expenses divided by profit before interest and tax paid. The following firm-specific characteristics are taken as control variables: leverage (LEV) is defined as total liabilities divided by total asset value. Capital intensity (CI) is defined as net fixed assets divided by total assets. Inventory intensity (II) is defined as inventory divided by total assets. Return on assets (ROA) is defined as pre-tax profits divided by total assets. Firm size (SIZE) is measured as the natural logarithm of total asset value. $\mathrm{D}_{t}$ is a time dummy to control for time-specific effects, such as changes in the macroeconomic environment over time. $\mathrm{IND}_{1} \ldots \mathrm{IND}_{\mathrm{n}}$ are the dummy variables which denoting different industries ( 1 if the firm operates primarily in the industry; 0 otherwise). The main explanatory state ownership variable is defined as the ratio of state-owned shares over total outstanding shares and denoted as S1.

The sample data used is collected from the Taiwan Economic Journal (TEJ) data base. It consists of companies listed in Chinese two largest stock markets, the Shanghai Security Exchange and the Shenzhen Security Exchange, in the twelve-year period 1999 to 2010. The database uses China Corporate Credit Risk Index (CCCRI) to embody information of firms.

There are two features of listed companies in China: 1. restructuring of state-owned enterprises; 2 . recurring asset replacement. CCCRI offers more accounting analysis interpretation of the two features. Follow previous research, this study deletes some observations using the following criteria: firms with missing data; firms in financial sectors; and 
firms with negative pre-tax income or tax expenses in any year of the sample period. The resulting sample thus includes 9939 observations.

Table 03 contains descriptive statistics of key variables included in this study over the period between 2000 and 2010. A mean ETR of $16.8 \%$ is below the statutory tax rates (Before year 2008 is 33\% and after year 2008 is $25 \%$ ).

\begin{tabular}{llllll}
\hline \multicolumn{5}{c}{ Table 03: Descriptive statistics } \\
\hline & \multicolumn{1}{c}{ Mean } & Median & Maximum & Minimum & SD \\
\hline ETR1 & 0.168 & 0.148 & 0.991 & 0.000 & 0.115 \\
SIZE & 13.934 & 13.829 & 21.372 & 5.787 & 1.444 \\
LEV & 0.032 & 0.000 & 0.616 & 0.000 & 0.080 \\
ROA & 0.073 & 0.060 & 12.751 & 0.322 & 0.175 \\
II & 0.169 & 0.130 & 0.903 & 0.002 & 0.154 \\
CI & 0.289 & 0.256 & 0.960 & 0.000 & 0.188 \\
S1 & 0.311 & 0.316 & 1.000 & 0.000 & 0.267 \\
\hline
\end{tabular}

The means of SIZE, LEV, ROA, II, and CI are 13.934, 0.032, 0.073, 0.169, 0.289; respectively. The average percentage of shares held by government is $31.1 \%$ in our sample.

\subsection{Empirical results}

Hsieh (2013) indicates that Quantile regression model not only explains different levels of ETR across firms when tax policies offer a variety of tax preferences but also considers the extreme low or high ETRs (i.e., OLS estimation may be strongly influenced by extreme values). This paper employs both OLS model and QR model for empirical study.

The results are reported in Table 04 in the first column we present the results obtained using the standard OLS procedure. In the further columns we report the regression results for nine different quantiles of the ETR distribution.

The coefficient of firm size is positive and statistically significant from OLS model. This result supports the political cost hypothesis. Quantile regression model shows fruitful in empirical results. From the10th to the 60th quantiles, the coefficients are all positive and statistically significant (i.e., political cost hypothesis). On the contrary, the coefficients of the 80th and the 90th quantiles are negative and statistically significant, (i.e., political power hypothesis). Finally, the coefficient of 70th quantile is statistically insignificant. Those results from quantile model explain why previous research cannot get the consistency results (e.g., Zimmerman, 1983 observes a positive association between ETR and firm size; Porcano, 1986 observes a negative association; Stickney and McGee, 1982 find no association between ETR and firm size).

The coefficient for capital intensive is statistically insignificant from OLS model. This evidence indicates that capital investment does not have higher depreciable costs and does not lead a lower ETR. However, results from quantile model are more interesting and really indicate that tax codes have heterogeneous tax preferences, not all firms can enjoy the same tax incentives. The coefficient of the 10th quantile is negative and statistically significant and this result indicates 10 th quantile has higher depreciable costs and lead a lower ETR. The 20th and the 30th quantile are statistically insignificant. The coefficients from the 40th quantile to the 90th quantile are all positive and statistically significant. Thus, only 10th quantile can enjoy the tax preferences. The coefficients for inventory intensity are all positive statistically (both OLS model and quantile regression model). These results are consistent with previous research. The coefficients of ROA, the measure for efficiency in performance, both OLS model and Quantile regression model are all not statistically different from zero except the 90th quantile has negative and statistically from zero. These evidences indicate firms make good explicitly control income associated with tax preferences. Thus, good performance will not create higher ETRs. 


\begin{tabular}{|c|c|c|c|c|c|c|c|c|c|c|}
\hline \multicolumn{2}{|c|}{ OLS estimates } & \multicolumn{9}{|c|}{ Quantile regression estimates (with industry effects) } \\
\hline & & 0.1 & 0.2 & 0.3 & 0.4 & 0.5 & 0.6 & 0.7 & 0.8 & 0.9 \\
\hline \multirow[t]{2}{*}{ INTERCEPT } & $0.089 * * *$ & $-0.083^{* * *}$ & $-0.069 * * *$ & -0.027 & 0.017 & $0.048^{* * *}$ & $0.066^{* * *}$ & $0.102^{* * *}$ & $0.197^{* * *}$ & $0.038^{* * *}$ \\
\hline & (0.011) & $(0.010)$ & (0.013) & $(0.018)$ & $(0.017)$ & $(0.016)$ & $(0.015)$ & $(0.015)$ & $(0.014)$ & $(0.017)$ \\
\hline \multirow[t]{2}{*}{ SIZE } & $0.003^{* * *}$ & $0.010^{* * *}$ & $0.010^{* * *}$ & $0.008^{* * *}$ & $0.006^{* * *}$ & $0.004^{* * *}$ & $0.003^{* * *}$ & 0.001 & $-0.004^{* * *}$ & $-0.009 * * *$ \\
\hline & $(0.001)$ & $(0.001)$ & $(0.001)$ & $(0.001)$ & $(0.001)$ & $(0.001)$ & $(0.001)$ & $(0.001)$ & $(0.001)$ & $(0.001)$ \\
\hline \multirow[t]{2}{*}{ CI } & 0.010 & $-0.014^{*}$ & -0.008 & 0.005 & $0.014^{* * *}$ & $0.016^{* * *}$ & $0.032^{* * *}$ & $0.040^{* * *}$ & $0.038^{* * *}$ & $0.009^{* * *}$ \\
\hline & $(0.007)$ & $(0.007)$ & $(0.007)$ & $(0.006)$ & $(0.005)$ & $(0.006)$ & $(0.009)$ & $(0.012)$ & $(0.012)$ & $(0.015)$ \\
\hline \multirow[t]{2}{*}{ ROA } & -0.003 & 0.004 & 0.007 & 0.017 & 0.027 & 0.036 & 0.044 & 0.055 & 0.072 & $-0.023^{* * *}$ \\
\hline & $(0.006)$ & $(0.011)$ & $(0.001)$ & $(0.052)$ & $(0.053)$ & $(0.057)$ & $(0.057)$ & $(0.060)$ & $(0.050)$ & $(0.007)$ \\
\hline \multirow[t]{2}{*}{ II } & $0.123^{* * *}$ & $0.054^{* * *}$ & $0.088^{* * *}$ & $0.097^{* * *}$ & $0.100^{* * *}$ & $0.114^{* * *}$ & $0.145^{* * *}$ & $0.160^{* * *}$ & $0.159 * * *$ & $0.133^{* * *}$ \\
\hline & $(0.008)$ & $(0.010)$ & $(0.010)$ & $(0.007)$ & $(0.007)$ & $(0.009)$ & (0.011) & $(0.013)$ & $(0.014)$ & $(0.019)$ \\
\hline \multirow[t]{2}{*}{ LEV } & $-0.054^{* * *}$ & 0.001 & $-0.041^{* * *}$ & $-0.065^{* * *}$ & $-0.058^{* * *}$ & $-0.051^{* * *}$ & $-0.067^{* * *}$ & $-0.088^{* * *}$ & $-0.111^{* * *}$ & $-0.146^{* * *}$ \\
\hline & (0.014) & $(0.013)$ & (0.013) & $(0.016)$ & (0.018) & (0.019) & (0.021) & $(0.014)$ & (0.023) & $(0.023)$ \\
\hline \multirow[t]{2}{*}{ S1 } & $0.012^{* * *}$ & -0.005 & 0.006 & $0.025^{* * *}$ & $0.019 * * *$ & $0.020^{* * *}$ & $0.019^{* * *}$ & $0.031^{* * *}$ & $0.044^{* * *}$ & 0.045 \\
\hline & $(0.004)$ & $(0.005)$ & $(0.004)$ & $(0.005)$ & $(0.004)$ & $(0.004)$ & $(0.006)$ & $(0.009)$ & $(0.008)$ & $(0.009)$ \\
\hline \multirow[t]{2}{*}{ YEAR2000 } & 0.005 & $-0.014^{*}$ & -0.005 & -0.006 & -0.004 & 0.000 & 0.003 & 0.003 & 0.006 & $0.025^{*}$ \\
\hline & $(0.006)$ & $(0.008)$ & $(0.005)$ & $(0.007)$ & $(0.005)$ & $(0.005)$ & $(0.005)$ & $(0.008)$ & $(0.014)$ & $(0.014)$ \\
\hline \multirow[t]{2}{*}{ YEAR2001 } & -0.003 & $-0.017^{* *}$ & $-0.011^{* *}$ & -0.009 & $-0.013^{* * *}$ & $-0.011^{* *}$ & $-0.007^{*}$ & -0.004 & $0.001^{* * *}$ & 0.018 \\
\hline & $(0.005)$ & $(0.007)$ & $(0.005)$ & $(0.006)$ & $(0.004)$ & $(0.005)$ & $(0.004)$ & $(0.008)$ & (0.015) & $(0.015)$ \\
\hline \multirow[t]{2}{*}{ YEAR2002 } & $0.027^{* * *}$ & -0.006 & -0.001 & 0.006 & $0.010^{* *}$ & $0.020^{* * *}$ & $0.033^{* * *}$ & $0.046^{* * *}$ & $0.060^{* * *}$ & $0.054^{* * *}$ \\
\hline & $(0.005)$ & $(0.008)$ & $(0.005)$ & $(0.007)$ & $(0.004)$ & $(0.005)$ & $(0.004)$ & $(0.008)$ & $(0.010)$ & $(0.009)$ \\
\hline \multirow[t]{2}{*}{ YEAR2003 } & $0.025^{* * *}$ & -0.011 & $-0.008^{* *}$ & 0.000 & 0.001 & $0.012^{* *}$ & $0.028^{* * *}$ & $0.047^{* * *}$ & $0.064^{* * *}$ & $0.061^{* * *}$ \\
\hline & $(0.005)$ & $(0.007)$ & $(0.004)$ & $(0.007)$ & $(0.005)$ & $(0.005)$ & $(0.006)$ & $(0.010)$ & $(0.010)$ & (0.008) \\
\hline \multirow[t]{2}{*}{ YEAR2004 } & $0.025^{* * *}$ & -0.012 & -0.009 & 0.002 & 0.002 & $0.011^{*}$ & $0.022^{* * *}$ & $0.045^{* * *}$ & $0.070^{* * *}$ & $0.063^{* * *}$ \\
\hline & $(0.006)$ & $(0.007)$ & $(0.006)$ & $(0.008)$ & $(0.005)$ & $(0.006)$ & $(0.008)$ & $(0.010)$ & $(0.011)$ & $(0.008)$ \\
\hline \multirow[t]{2}{*}{ YEAR2005 } & $0.028^{* * *}$ & $-0.017^{* * *}$ & $-0.009^{*}$ & -0.004 & 0.001 & $0.013^{* * *}$ & $0.025^{* * *}$ & $0.051^{* * *}$ & $0.075^{* * *}$ & $0.079^{* * *}$ \\
\hline & $(0.006)$ & $(0.006)$ & $(0.005)$ & $(0.007)$ & $(0.005)$ & $(0.004)$ & $(0.006)$ & $(0.011)$ & $(0.013)$ & $(0.011)$ \\
\hline \multirow[t]{2}{*}{ YEAR2006 } & $0.024^{* * *}$ & $-0.019^{* * *}$ & $-0.013^{* * *}$ & -0.008 & -0.006 & $0.010^{*}$ & $0.025^{* * *}$ & $0.048^{* * *}$ & $0.070^{* * *}$ & $0.066^{* * *}$ \\
\hline & $(0.005)$ & $(0.007)$ & $(0.004)$ & $(0.005)$ & $(0.005)$ & $(0.006)$ & $(0.008)$ & $(0.009)$ & $(0.015)$ & $(0.013)$ \\
\hline \multirow[t]{2}{*}{ YEAR2007 } & $0.043^{* * *}$ & $-0.022^{* *}$ & -0.009 & 0.003 & 0.006 & $0.022^{* * *}$ & $0.039 * * *$ & $0.069 * * *$ & $0.092^{* * *}$ & $0.098^{* * *}$ \\
\hline & $(0.043)$ & $(0.009)$ & $(0.006)$ & $(0.007)$ & $(0.006)$ & $(0.005)$ & $(0.006)$ & $(0.010)$ & $(0.010)$ & $(0.012)$ \\
\hline \multirow[t]{2}{*}{ YEAR2008 } & $0.036^{* * *}$ & $-0.018^{* *}$ & $-0.013^{* * *}$ & 0.004 & $0.008^{*}$ & $0.017^{* * *}$ & $0.033^{* * *}$ & $0.051^{* * *}$ & $0.061^{* * *}$ & $0.077^{* * *}$ \\
\hline & $(0.006)$ & $(0.008)$ & $(0.005)$ & $(0.006)$ & $(0.005)$ & $(0.005)$ & $(0.007)$ & $(0.008)$ & $(0.010)$ & $(0.013)$ \\
\hline \multirow[t]{2}{*}{ YEAR2009 } & $0.021^{* * *}$ & $-0.029 * * *$ & -0.006 & 0.007 & $0.008^{*}$ & $0.019 * * *$ & $0.024^{* * *}$ & $0.036^{* * *}$ & $0.049 * * *$ & $0.039^{* * *}$ \\
\hline & $(0.006)$ & $(0.008)$ & $(0.004)$ & $(0.006)$ & $(0.004)$ & $(0.004)$ & $(0.005)$ & $(0.006)$ & $(0.013)$ & $(0.013)$ \\
\hline \multirow[t]{2}{*}{ YEAR2010 } & 0.0063 & $-0.014^{* * *}$ & 0.004 & $0.012^{*}$ & $0.014^{* * *}$ & .009 & 0.002 & -0.003 & -0.007 & -0.006 \\
\hline & $(00059)$ & $(0.005)$ & $(0.005)$ & $(0.007)$ & $(0.005)$ & $(0.006)$ & $(0.008)$ & $(0.011)$ & $(0.011)$ & (0.013) \\
\hline
\end{tabular}

Notes: $1 . S t a n d a r d$ errors are in parentheses. ${ }^{*}$ Significant at the $10 \%$ level; ${ }^{* *}$ significant at the $5 \%$ level; ${ }^{* * *}$ significant at the $1 \%$ level. 
Figure 01: Quantile regression results at tau $=\{0.1,0.2,0.3,0.4,0.5,0.6,0.7,0.8,0.9\}$ for ETR. The gray area is the 95 confidence band. The horizontal solid line is the result from OLS. The dashed zero line is for the visual convenience of the coefficient of significance.

SIZE

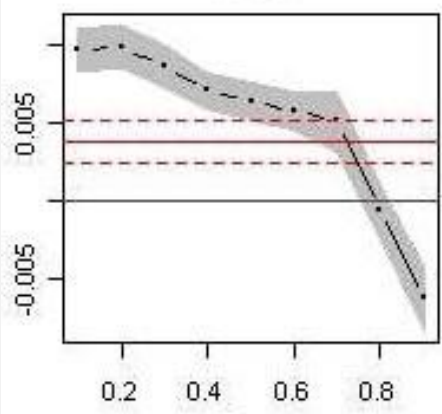

II

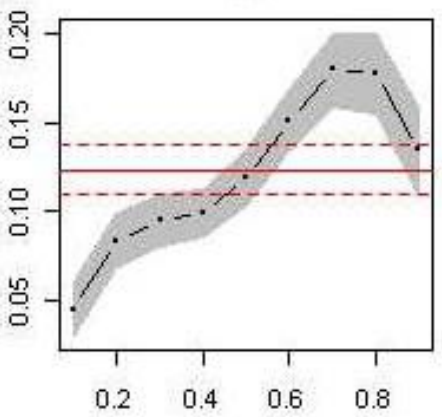

$\mathrm{Cl}$

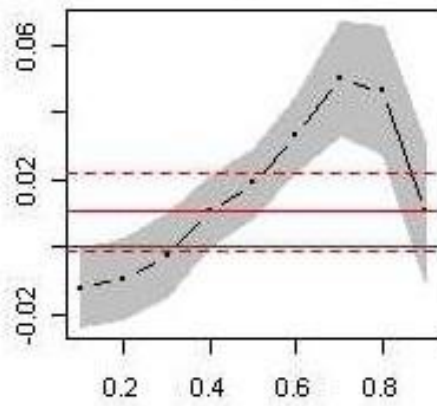

LEV

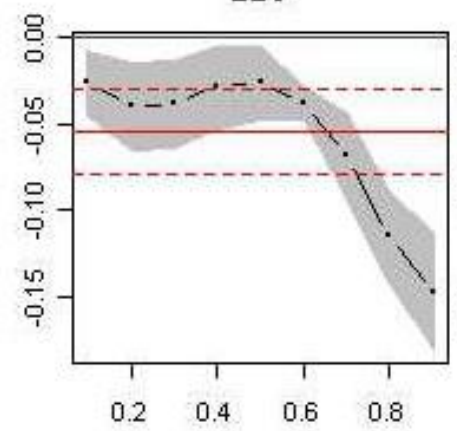

ROA

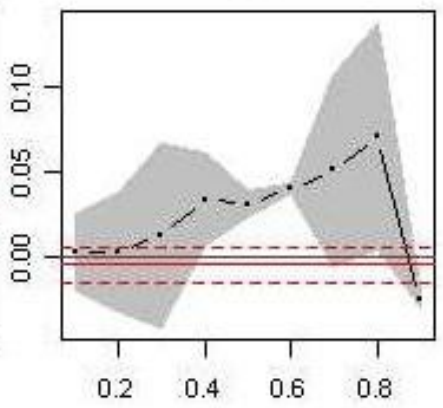

S1

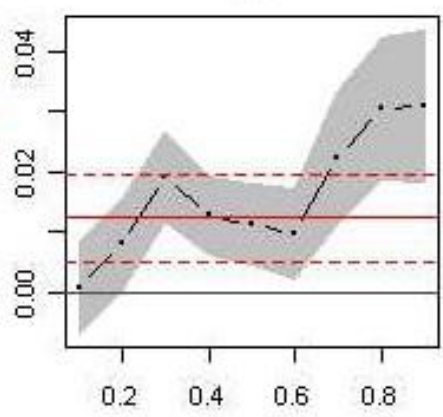

The coefficients for leverage are negative and statistically significant except 10th quantile. Thus, these results appear that debt financing can be used as a tax shelter for China's firms, and from the quantile regression results we can find the higher quantile, the higher tax shelter. Before we discuss state ownership variable we first demonstrate why quantile regression approach can explain the benefits of tax preferences. The quantile regression method (reported in Table 04 and illustrated graphically in Fig. 01) allows for a more detailed interpretation when we analyze the empirical results about the determinants of ETR.

The regression quantile results give a more precise picture of the importance of the explanatory variables for the different quantiles. Comparing the results for the different quantiles shows that the magnitude of the coefficients changes as we move along the ETR distribution of firms. The estimated coefficients on all independent variables are examined at the 10 th, 20 th, 30th, 40th, 50th, 60th, 70th, 80th and 90th quantiles.

Looking at the standard OLS results we find that, as expected, in almost all of the panels of Figure 01, the quantile regression estimates lie at some point outside the confidence intervals for the ordinary least squares regression, suggesting that the effects of these covariates may not be constant across the conditional distribution of the independent variable. Those situations indicate that tax incentives are offered by different tax codes. 


\begin{tabular}{|c|c|c|c|c|c|c|c|c|c|c|}
\hline \multirow{2}{*}{\multicolumn{2}{|c|}{ OLS estimates }} & \multirow{2}{*}{\multicolumn{9}{|c|}{$\begin{array}{l}\text { Quantile regression models (E } \\
\text { Quantile regression estimates }\end{array}$}} \\
\hline & & \multirow[b]{2}{*}{0.1} & & & & e regression est & mates & & & \\
\hline & & & 0.2 & 0.3 & 0.4 & \multirow[b]{2}{*}{$0.059 * * *$} & \multirow{2}{*}{$0.6 \quad 0.081^{* * *}$} & \multirow{2}{*}{$\begin{array}{ll}0.7 & \\
0.124^{* * *}\end{array}$} & \multirow[b]{2}{*}{$0.213^{* * *}$} & 0.9 \\
\hline \multirow[t]{2}{*}{ INTERCEPT } & $0.117^{* * *}$ & $-0.082^{* * *}$ & $-0.057^{* * *}$ & -0.012 & $0.035^{* * *}$ & & & & & 0.357 \\
\hline & $(0.012)$ & $(0.019)$ & $(0.016)$ & $(0.017)$ & $(0.012)$ & $(0.013)$ & $(0.014)$ & $(0.021)$ & $(0.016)$ & $(0.016)$ \\
\hline \multirow[t]{2}{*}{ SIZE } & 0.001 & $0.009 * * *$ & $0.009 * * *$ & $0.006^{* * *}$ & $0.004^{* * *}$ & $0.003^{* * *}$ & 0.002 & -0.001 & $-0.005^{* * *}$ & $-0.010^{* * *}$ \\
\hline & $(0.001)$ & $(0.001)$ & $(0.001)$ & $(0.000)$ & $(0.001)$ & $(0.001)$ & $(0.001)$ & $(0.002)$ & $(0.001)$ & (0.001) \\
\hline \multirow[t]{2}{*}{$\mathrm{CI}$} & $0.019^{* *}$ & -0.008 & -0.007 & 0.008 & $0.017^{* * *}$ & $0.027^{* * *}$ & $0.037^{* * *}$ & $0.039^{* * *}$ & $0.039 * * *$ & 0.011 \\
\hline & $(0.007)$ & $(0.008)$ & (0.008) & $(0.169)$ & $(0.006)$ & $(0.009)$ & $(0.009)$ & $(0.008)$ & $(0.008)$ & $(0.010)$ \\
\hline \multirow[t]{2}{*}{ ROA } & 0.001 & 0.001 & 0.017 & 0.058 & $0.054 * * *$ & 0.060 & 0.088 & 0.084 & $0.081 *$ & -0.023 \\
\hline & $(0.007)$ & $(0.032)$ & $(0.071)$ & $(0.468)$ & $(0.077)$ & $(0.069)$ & $(0.075)$ & $(0.078)$ & $(0.040)$ & $(0.034)$ \\
\hline \multirow[t]{2}{*}{ II } & $0.115^{* * *}$ & $0.052^{* * *}$ & $0.085^{* * *}$ & $0.091^{* * *}$ & $0.096^{* * *}$ & $0.120^{* * *}$ & $0.138^{* * *}$ & $0.151^{* * *}$ & $0.140^{* * *}$ & $0.112^{* * *}$ \\
\hline & $(0.009)$ & $(0.017)$ & $(0.013)$ & $(0.000)$ & $(0.009)$ & $(0.011)$ & $(0.012)$ & $(0.011)$ & $(0.010)$ & $(0.014)$ \\
\hline \multirow[t]{2}{*}{ LEV } & $-0.061^{* * *}$ & 0.010 & $-0.038^{* * *}$ & $-0.066^{* * *}$ & $-0.052 * * *$ & $-0.045^{* * *}$ & $-0.061^{* * *}$ & $-0.087^{* * *}$ & $-0.108^{* * *}$ & $-0.116^{* * *}$ \\
\hline & $(0.015)$ & $(0.019)$ & $(0.017)$ & $(0.001)$ & $(0.015)$ & $(0.013)$ & $(0.012)$ & $(0.012)$ & $(0.020)$ & $(0.027)$ \\
\hline \multirow[t]{2}{*}{ S1 } & $0.023^{* * *}$ & 0.000 & 0.007 & $0.025^{* * *}$ & $0.020^{* * *}$ & $0.021^{* * *}$ & $0.024^{* * *}$ & $0.031^{* * *}$ & $0.050^{* * *}$ & $0.044^{* * *}$ \\
\hline & $(0.005)$ & $(0.006)$ & $(0.007)$ & $(0.006)$ & $(0.005)$ & $(0.005)$ & $(0.006)$ & $(0.007)$ & $(0.007)$ & $(0.007)$ \\
\hline \multirow[t]{2}{*}{ YEAR2000 } & 0.005 & -0.013 & -0.004 & -0.007 & -0.003 & 0.000 & 0.002 & 0.004 & 0.009 & 0.025 \\
\hline & $(0.005)$ & $(0.010)$ & $(0.007)$ & $(0.005)$ & $(0.004)$ & $(0.005)$ & $(0.005)$ & $(0.006)$ & $(0.010)$ & $(0.013)$ \\
\hline \multirow[t]{2}{*}{ YEAR2001 } & -0.002 & $-0.015^{* *}$ & $-0.010^{*}$ & $-0.009^{*}$ & $-0.012^{* *}$ & $-0.010^{*}$ & -0.006 & -0.004 & 0.005 & 0.015 \\
\hline & $(0.005)$ & $(0.007)$ & $(0.006)$ & $(0.005)$ & $(0.005)$ & $(0.005)$ & $(0.004)$ & $(0.007)$ & (0.009) & $(0.011)$ \\
\hline \multirow[t]{2}{*}{ YEAR2002 } & $0.028^{* * *}$ & -0.006 & 0.001 & 0.007 & $0.011^{*}$ & $0.021^{* * *}$ & $0.034^{* * *}$ & $0.047^{* * *}$ & $0.063^{* * *}$ & $0.051^{* * *}$ \\
\hline & $(0.005)$ & $(0.008)$ & $(0.005)$ & $(0.007)$ & $(0.006)$ & $(0.005)$ & $(0.006)$ & $(0.008)$ & $(0.011)$ & $(0.010)$ \\
\hline \multirow[t]{2}{*}{ YEAR2003 } & $0.026^{* * *}$ & -0.009 & -0.006 & 0.003 & 0.003 & $0.014^{* * *}$ & $0.029^{* * *}$ & $0.050^{* * *}$ & $0.068^{* * *}$ & $0.060^{* * *}$ \\
\hline & $(0.005)$ & $(0.006)$ & $(0.006)$ & $(0.005)$ & $(0.006)$ & $(0.005)$ & $(0.007)$ & $(0.010)$ & $(0.010)$ & $(0.013)$ \\
\hline \multirow[t]{2}{*}{ YEAR2004 } & $0.027^{* * *}$ & -0.009 & -0.007 & 0.004 & 0.005 & $0.011^{* *}$ & $0.023^{* * *}$ & $0.046^{* * *}$ & $0.073^{* * *}$ & $0.063^{* * *}$ \\
\hline & $(0.005)$ & $(0.009)$ & $(0.006)$ & $(0.006)$ & $(0.007)$ & $(0.006)$ & $(0.006)$ & $(0.009)$ & $(0.009)$ & $(0.008)$ \\
\hline \multirow[t]{2}{*}{ YEAR2005 } & $0.030^{* * *}$ & $-0.013^{*}$ & -0.007 & -0.003 & 0.005 & $0.014^{* *}$ & $0.027^{* * *}$ & $0.052^{* * *}$ & $0.079 * * *$ & $0.077^{* * *}$ \\
\hline & $(0.006)$ & $(0.008)$ & $(0.006)$ & $(0.006)$ & $(0.006)$ & $(0.006)$ & $(0.007)$ & $(0.010)$ & $(0.006)$ & $(0.011)$ \\
\hline YEAR2006 & $0.027^{* * *}$ & $-0.017^{* *}$ & -0.011 & -0.006 & -0.002 & $0.011^{*}$ & $0.027^{* * *}$ & $0.050^{* * *}$ & $0.074^{* * *}$ & $0.066^{* * *}$ \\
\hline & $(0.005)$ & $(0.008)$ & $(0.007)$ & $(0.008)$ & $(0.008)$ & $(0.006)$ & $(0.009)$ & $(0.009)$ & $(0.009)$ & $(0.010)$ \\
\hline YEAR2007 & $0.042^{* * *}$ & $-0.023^{* * *}$ & $-0.010^{*}$ & 0.007 & $0.011^{* * *}$ & $0.026^{* * *}$ & $0.050 * * *$ & $0.082^{* * *}$ & $0.101^{* * *}$ & $0.103^{* * *}$ \\
\hline & $(0.006)$ & $(0.008)$ & $(0.005)$ & $(0.005)$ & $(0.004)$ & $(0.005)$ & $(0.008)$ & $(0.007)$ & $(0.009)$ & $(0.010)$ \\
\hline YEAR2008 & 0.008 & $-0.044^{* * *}$ & $-0.029 * * *$ & -0.008 & -0.001 & 0.007 & $0.019 * * *$ & $0.034^{* * *}$ & $0.043^{* * *}$ & $0.036^{* *}$ \\
\hline & $(0.006)$ & $(0.009)$ & $(0.006)$ & $(0.008)$ & $(0.006)$ & $(0.005)$ & $(0.007)$ & $(0.008)$ & $(0.009)$ & $(0.016)$ \\
\hline YEAR2009 & $0.015^{* *}$ & $-0.027^{* * *}$ & -0.010 & 0.008 & 0.008 & $0.014^{* *}$ & $0.027^{* * *}$ & $0.036^{* * *}$ & $0.051^{* * *}$ & $0.028^{* * *}$ \\
\hline & $(0.006)$ & $(0.007)$ & (0.008) & $(0.009)$ & $(0.007)$ & $(0.007)$ & $(0.007)$ & $(0.008)$ & $(0.010)$ & $(0.010)$ \\
\hline YEAR2010 & -0.008 & $-0.022^{* * *}$ & -0.003 & 0.006 & 0.007 & 0.002 & -0.005 & -0.015 & $-0.018^{* * *}$ & $-0.032^{* * *}$ \\
\hline & $(0.006)$ & $(0.006)$ & $(0.005)$ & $(0.006)$ & $(0.006)$ & $(0.006)$ & $(0.007)$ & $(0.009)$ & $(0.007)$ & $(0.008)$ \\
\hline
\end{tabular}

Notes: 1. Standard errors are in parentheses. * Significant at the $10 \%$ level; ${ }^{* *}$ significant at the $5 \%$ level; ${ }^{* * *}$ significant at the $1 \%$ level.

2. Industry effects are not included in the table. 


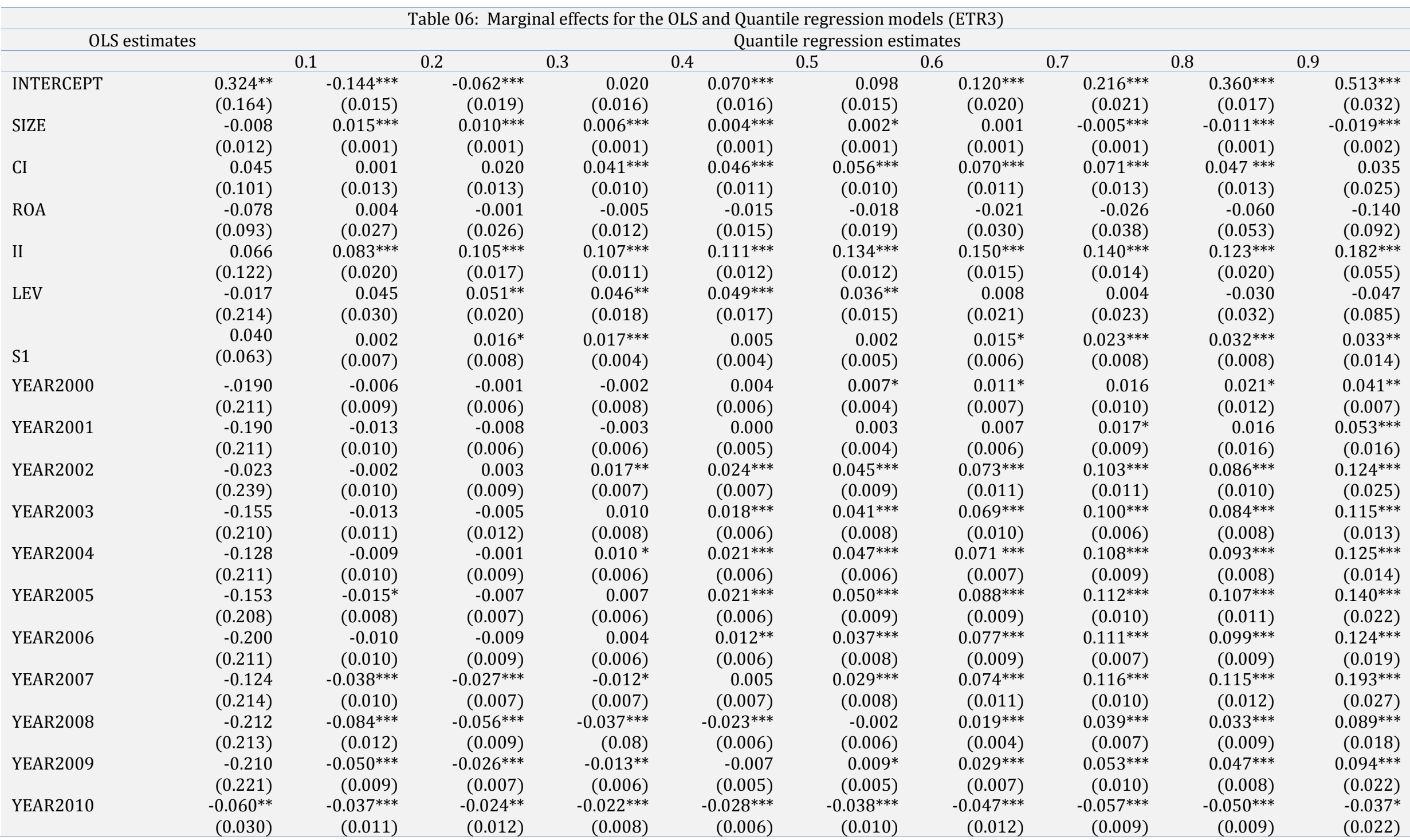

Notes: 1. Standard errors are in parentheses. ${ }^{*}$ Significant at the $10 \%$ level; ${ }^{* *}$ significant at the $5 \%$ level; ${ }^{* * *}$ significant at the $1 \%$ level.

2. Industry effects are not included in the table. 
Table 07: Marginal effects for the OLS and Quantile regression models (ETR4)

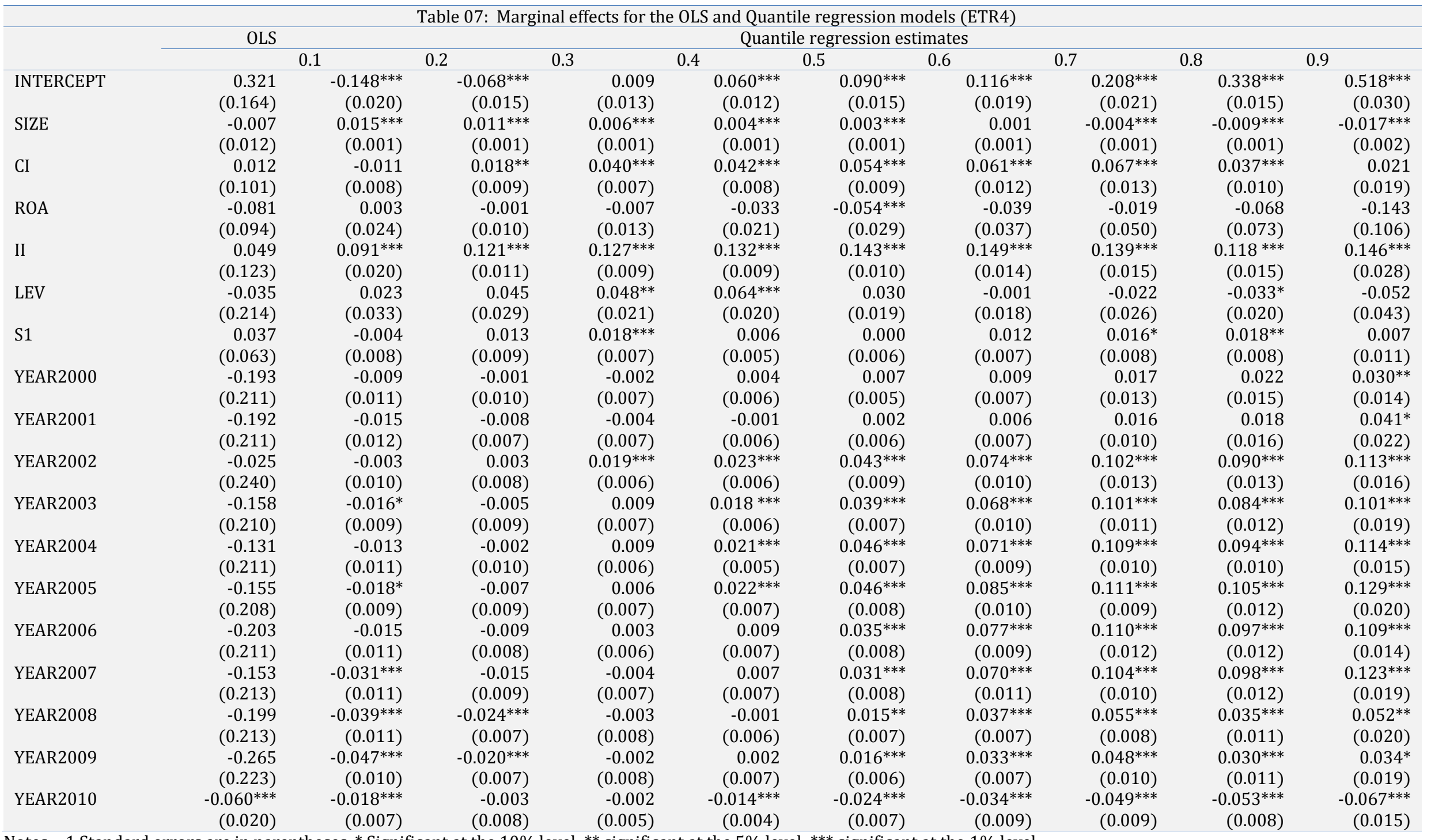

Notes: 1. Standard errors are in parentheses. ${ }^{*}$ Significant at the $10 \%$ level; ${ }^{* *}$ significant at the $5 \%$ level; ${ }^{* * *}$ significant at the $1 \%$ level.

2 . Industry effects are not included in the table. 
Now we focus on state ownership variable, our main concern in this study. The coefficients for state ownership variable are positive significantly different from zero except 10th quantile, which suggests that ETRs are associated with the state-owned shares. Figs.01 shows the quantile plots for estimated coefficients, the regression coefficient at given quantile denotes the effect on the ETRs of a unit change in that variable. The coefficient for the state-owned shares is outside the 95 confidence interval of the OLS regression in the10th, 70th, 80th and 90th quantiles. This means that the state-owned shares in this part of the distribution differs significantly from that of the OLS estimates. For the 0.2 to 0.6 quantiles the estimates are not much different from the OLS estimate because they all fall in the 95 confidence interval of the OLS estimate. Both results of OLS and quantile regression demonstrate that ETRs are associated with state-owned shares. In terms of the relationship between the state-owned shares and ETRs for the various quantiles, the plot shows a rising trend. The effect of state-owned shares on ETRs obvious increases the positive impact when state ownership variable goes beyond the 60th quantile. Those above evidences support our state-owned hypothesis.

To test the relationship between ETR and state ownership, we use alternative measurements of independent variables to run the regressions and improve the robustness of empirical results. Deferred taxes play a very important role when we measure the effective tax rates. First, including deferred taxes or not will significant impact on firm's tax burden and profit. Some researchers suggest deferred taxes should be included, others, on the contrary, exclude the deferred portion. Second, how to measure profit is another issue because the treatment of accounting income and taxable income is different. Accounting income requires income and expenses are matched to the period in which they are incurred; however, taxable income and expenses are matched to the period upon which the tax code decides. This means that an accounting income may not be considered an accounting profit under tax rules.

Besides, Derashid and Zhang (2003) suggest different ETR measures can avoid producing conflicting results. Thus, three different ETR' definitions, ETR2, ETR3, and ETR4, measures are used. ETR2 is another version of the measure used by Porcano (1986): (tax expenses)/ (profit before interest and tax). ETR3 is the measure used by Stickney and McGee (1982) and is given as (tax expenses)/ (pre-tax profit- (deferred tax expenses/statutory tax rate)). ETR4 is the measure used by Shevlin (1987) and is calculated as (tax expenses-deferred tax expenses)/ (pre-tax profit (changes in deferred tax/statutory tax rate)). Zimmerman (1983) considers cash flow rather than operating income to eliminate the effects of different accounting treatment on income and defines ETR as (tax expenses-deferred tax expenses)/ (pre-tax profit -operating cash flow).This article will not use this definition because fiscal reforms in China emphasize how state-owned enterprises pay their taxes after tax regulations.

The empirical results show in Table 05, 06, and 07, respectively. The results of Table 05, using the definition of ETR2, are almost the same as results of ETR1. The OLS estimates reported in Table 06 and Table 07, using the definitions of ETR3 and ETR4, indicate that state ownership variable is statistically insignificant but the results of quantile regressions are positive significantly different from zero (except some quantiles are insignificantly different from zero) and pretty close to the results of ETR1 and ETR2. Therefore, we can confirm that ETRs are associated with the state-owned shares and the effect of state-owned shares on ETRs increases the positive impact when state ownership variable goes beyond around the 60th quantile in China.

\subsection{Conclusion and policy implication}

2008 China Enterprise Income Tax Reform, take much for the correction, such as: (1) the uniform application of foreign enterprise income tax law; (2) reduce the tax rate to 25 percent; (3) the foreign tax deduction unified approach and standards ; (4) amendments to industrial policies. In this tax reform, Whether SOE is one of the determinants that affect ETR in China?

This study attempts to adopt institutional environments, the state-owned enterprises taxation reform and China's Communist Party on the regulations of state-owned enterprises, and proposes the state-owned enterprise hypothesis. Using a sample from companies listed on Shanghai and Shenzhen Stock Exchanges from 1999 to 2010, the empirical results support the state-owned enterprise hypothesis. That is, a statistically significant positive link between ETRs and SOEs.

The Chinese economic system reform, transforming from a highly centralized planned economy to a socialist market economy, can be described as the most significant economic change after China went into power. The approach of China's moving towards future economic development goals step by step is to deepen fiscal and financial reform and improve the macro-control system.

Since 1978 when China adopted the reform and opened up policy of Deng Xiaoping, resulting in a series of economic reform, fiscal reform policies have played a significant role in its effectiveness. After thirty years of economic reform, China has transformed into the world's second largest economy from a poor and backward country. Deng Xiaoping lived up to his name "Economic Chief Architect.". 
But it must be said, there are negative effects arising from the process of economic reform, such as: uneven distribution of wealth (resources), inflation, environmental pollution and the role played by the State, and so on. In this transformation of economic reform, how to remove the shortcomings and pursue positive stability and growth is the direction that China badly needs to face and think about in the future.

\section{References}

Adhikari, A., Derashid, C., \& Zhang, H., 2006. Public policy, political connections, and effective tax rates: Longitudinal evidence from Malaysia. Journal of Accounting and Public Policy, 25(5): 574-595. http://dx.doi.org/10.1016/j.jaccpubpol.2006.07.001

Bai, C., Liu, Q., Lu, J., Song, F., \& Zhang, J., 2004. Corporate governance and market valuation in China. Journal of Comparative Economics, 32(4): 599-616. http://dx.doi.org/10.1016/j.jce.2004.07.002

Derashid, C., \& Zhang, H., 2003. Effective tax rates and the industrial policy hypothesis: evidence from Malaysia. Journal of International Accounting Auditing and Taxation, 12(1): 45-62. http://dx.doi.org/10.1016/S10619518(03)00003-X

Gupta, S., \& Newberry, K., 1997. Determinants of the variability of corporate effective tax rates: evidence from longitudinal data. Journal of Accounting and Public Policy, 16(1): 1-34. http://dx.doi.org/10.1016/S02784254(96)00055-5

Hsieh, Y.C., 2013. The heterogeneous relation between firm size and corporate effective tax rates: Evidence from listed companies in China. Journal of Interdisciplinary Mathematics, 16(4\&5): 297-308. http://dx.doi.org/10.1080/09720502.2013.778499

Huang, D., Chen, N., \& Gao, K., 2013. The tax burden of listed companies in China, Applied Financial Economics, 23(14): 1169-1183. http://dx.doi.org/10.1080/09603107.2013.786163

Kern, B. B., \& Morris, M. H., 1992. Taxes and firm size: the effect of tax legislation during the 1980s. Journal of the American Taxation Association, 14(1): 80-96.

Kim, K.A., \& Limpaphayom, P., 1998. Tax and firm size in Pacific-Basin emerging economies. Journal of International Accounting Auditing and Taxation, 7(1): 147-63. http://dx.doi.org/10.1016/S1061-9518(98)90005-2

Koenker, R., \& Bassett, G. (1978). Regression quantiles. Econometrica, 46(1): 33-50. http://dx.doi.org/10.2307/1913643

Koenker, R., \& Hallock, K., 2001. Quantile regression. Journal of Economic Perspectives, 15(4): $143-156$. http://dx.doi.org/10.1257/jep.15.4.143

Liu, X., \& Cao, S., 2007. Determinants of corporate effective tax rates: evidence from listed companies in China. The Chinese Economy, 40(6): 49-67. http://dx.doi.org/10.2753/CES1097-1475400603

Omer, T. C., Molloy, K. and Ziebart, D., 1993. An investigation of firm size-effective tax reat relation in the 1980s, Journal of Accounting and Finance, 8: 167-181.

Porcano, T. M., 1986. Corporate tax rates: progressive, proportional or regressive. Journal of the American Taxation Association, 7(2): 17-31.

Qi, D., Wu, W., \& Zhang, H., 2000. Shareholding structure and corporate performance of partially privatized firms: evidence from listed Chinese companies. Pacific-Basin Finance Journal, 8(5): 587-610. http://dx.doi.org/10.1016/S0927-538X(00)00013-5

Shevlin, T., 1987. Taxes and off-balance-sheet financing: Research and development limited partnership. The Accounting Review, 62(3): 480-509.

Shirai, S., 2004. Testing the three rules of equity markets in developing countries: The case of China. World Development, 32(9): 1467-1486. http://dx.doi.org/10.1016/j.worlddev.2004.05.001

Siegfried, J. 1974. Effective average U.S. corporation income tax rates. National Tax Journal 27(2): 245-259.

Stickney, C. P., \& McGee, V. E., 1982. Effective corporate tax rates: the effect of size, capital intensity, leverage and other factors. Journal of Accounting and Public Policy, 1(2): 125-152. http://dx.doi.org/10.1016/S02784254(82)80004-5

Sun, Q., \& Tong, W., 2003. China share issue privatization: the extent of its success. Journal of Financial Economics, 70(2): 182-222. http://dx.doi.org/10.1016/S0304-405X(03)00145-4

Sun, Q., Tong, W., \& Tong, J., 2002. How does government ownership affect firm performance? evidence from China's privatization process. Journal of Business, Finance \& Accounting, 29(1/2): 1-27. http://dx.doi.org/10.1111/1468-5957.00422

Tian, L., \& Estrin, S., 2008. Retained state shareholding in Chinese PLCs: does government ownership reduce corporate value? Journal of Comparative Economics, $36(1):$ 74-89. http://dx.doi.org/10.1016/j.jce.2007.10.003

Wilkie, P. J., \& Limberg, S. T., 1990. The relationship between from size and effective tax rate: a reconciliation of Zimmerman (1983) and Porcano (1986). The ournal of American Taxation Association, 11(2): 76-91.

Wu, L., Wang, Y., Lin, B., Li, C., \& Chen, S., 2007. Local tax rebates, corporate tax burdens, and firm migration: evidence from China. Journal of Accounting and Public Policy, 26(5): 555-583. http://dx.doi.org/10.1016/j.jaccpubpol.2007.08.003 
Xu, X., \& Wang, Y., 1999. Ownership structure and corporate governance in Chinese stock companies. China Economic Review, 10(1): 75-98. http://dx.doi.org/10.1016/S1043-951X(99)00006-1

Zimmerman, J. L., 1983. Taxes and firm size. Journal of Accounting and Economics, 5(2): $119-149$. http://dx.doi.org/10.1016/0165-4101(83)90008-3 